\title{
Genistein alleviates chronic vascular inflammatory response via the miR-21/NF-кB p65 axis in lipopolysaccharide-treated mice
}

\author{
XIAOLIN XIE ${ }^{1,2}$, LI CONG $^{1}$, SUJUAN LIU $^{2}$, LIPING XIANG $^{3}$ and XIAOHUA FU ${ }^{1,2}$ \\ ${ }^{1}$ Key Laboratory of Study and Discovery of Small Targeted Molecules of Hunan Province, Hunan Normal University; \\ ${ }^{2}$ Department of Basic Medicine, School of Medicine, Hunan Normal University, Changsha, Hunan 410013; \\ ${ }^{3}$ Department of Pathology, Renmin Hospital of Wuhan University, Wuhan, Hubei 430060, P.R. China
}

Received July 27, 2020; Accepted December 9, 2020

DOI: $10.3892 / \mathrm{mmr} .2021 .11831$

\begin{abstract}
Chronic vascular inflammatory response is an important pathological basis of cardiovascular disease. Genistein (GEN), a natural compound, exhibits anti-inflammatory effects. The aim of the present study was to investigate the effects of GEN on lipopolysaccharide (LPS)-induced chronic vascular inflammatory response in mice and explore the underlying anti-inflammatory mechanisms. C57BL/6 mice were fed with a high-fat diet combined with intraperitoneal injection of LPS to induce chronic vascular inflammation. The expression levels of TNF- $\alpha$, IL- 6 and microRNA (miR)-21 in the vasculature were detected via reverse transcription-quantitative (RT-q)PCR. The protein levels of inducible nitric oxide synthase (iNOS) and NF- $\kappa$ B p65 were detected via western blotting. NF- $\kappa \mathrm{B}$ p65 was also analyzed via immunohistochemistry and immunofluorescence (IF). In addition, after transfection with miR-21 mimic or inhibitor for $24 \mathrm{~h}$, vascular endothelial cells (VECs) were treated with GEN and LPS. RT-qPCR and western blot analyses were performed to detect the expression of TNF- $\alpha$, IL-6, miR-21 and iNOS, and the protein levels of iNOS and NF- $\kappa \mathrm{B}$ p 65 , respectively. IF was used to measure NF- $\kappa$ B p65 nuclear translocation. The results revealed that GEN significantly decreased the expression of inflammation-associated vascular factors in LPS-treated C57BL/6 mice, including TNF- $\alpha$, IL-6, iNOS, NF- $\mathrm{B}$ p65 and miR-21. Furthermore, miR-21 antagomir enhanced the anti-inflammatory effects of GEN. In LPS-induced VECs, miR-21 mimic increased inflammation-associated factor expression and attenuated the anti-inflammatory effects of GEN, whereas miR-21 inhibitor induced opposing effects. Therefore, the results of the present study suggested that GEN inhibited chronic vascular inflammatory response in mice,
\end{abstract}

Correspondence to: Professor Xiaohua Fu, Department of Basic Medicine, School of Medicine, Hunan Normal University, 371 Tongzipo Road, Changsha, Hunan 410013, P.R. China

E-mail: fuxh1@126.com

Key words: genistein, microRNA-21, lipopolysaccharide, chronic vascular inflammatory response, vascular endothelial cells which may be associated with the inhibition of VEC inflammatory injury via the miR-21/NF- $\mathrm{BB}$ p65 pathway.

\section{Introduction}

Chronic vascular inflammation is an important pathophysiological basis of a number of cardiovascular diseases, including atherosclerosis, polyarteritis nodosa and aneurysms (1). Chemical, physical and other harmful factors damage vascular endothelial cells (VECs), resulting in functional and structural changes (2). Injured VECs release a variety of inflammatory factors and chemokines, which induce the local accumulation of lipids and inflammatory cells, ultimately triggering innate and adaptive inflammatory immune responses in the vascular intima (3). Therefore, protecting endothelial cells (ECs) is beneficial to reducing vascular inflammation, and preventing the occurrence and development of cardiovascular diseases.

Nonsteroidal anti-inflammatory drugs (NSAIDs) are a range of chemically unrelated compounds sharing certain common therapeutic actions (4). At present, NSAIDs that are commonly used clinically include aspirin, paracetamol and ibuprofen, and mainly act by inhibiting prostaglandin synthesis (5). However, there are serious side effects associated with these medications, such as gastrointestinal bleeding or perforation, liver injury, and actions on the urinary and nervous systems (6). Therefore, anti-inflammatory components from natural compounds have attracted increasing attention, offering a promising avenue for developing novel anti-inflammatory drugs.

Genistein (GEN), a natural isoflavone, is distributed widely in soybean and dentate plants, and exhibits similarities with human estrogen in terms of its chemical structure (7). Additionally, GEN not only inhibits the proliferation, and promotes the differentiation and apoptosis of various cancer cells, but it also exhibits anti-inflammatory, antioxidant, anti-angiogenic and lipid-regulating properties $(8,9)$. Liu et al (10) reported that GEN reduced focal adhesion kinase (FAK) expression and inhibited estradiol-induced VEC injury by downregulating the FAK pathway. Han et al (11) suggested that GEN protected homocysteine-induced EC inflammatory injury by reducing the release of reactive oxygen species (ROS) and cytokines regulating autophagy. Meanwhile, Deretic et al $(12,13)$ further 
proposed that autophagy deficiency is a predisposing factor for inflammatory disease. Additionally, GEN protects against oxidized low-density lipoprotein (ox-LDL)-induced senescence by enhancing sirtuin 1 (SIRT1)/liver kinase B1/AMP kinase-mediated autophagy flux (14), and reverses ox-LDLor lipopolysaccharide (LPS)-induced inflammatory responses via miR-34a/SIRT1/FOXO3a (15) and MyD88/NF-кB/BCL-2 signaling pathways in VECs (16). These findings suggest that GEN regulates microRNAs (miRNAs/miRs), autophagy and apoptosis, thus alleviating VEC injury triggered by various inducers; however, the underlying mechanisms are yet to be clearly defined.

miRNAs are highly conserved small non-coding RNAs that serve crucial roles in diverse physiological and pathological processes $(17,18)$. Increasing evidence has suggested that changes in miRNA expression profiles may be associated with chronic vascular inflammation, consisting of dysfunctions in ECs, macrophages and vascular smooth muscle cells (VSMCs) (19,20). For example, miR-126 and miR-125 directly target PI3K regulatory subunit 2 and vascular endothelial cadherin to regulate angiogenesis $(21,22)$. Additionally, miR-150 targets c-Myd and enhances the migration of ECs (23). A clinical study revealed that miR-21 expression in the serum of patients with cardiovascular disease was significantly increased, rendering it a potential novel independent biomarker of vascular inflammatory injury (24). Canfran-Duque et al (25) reported that miR-21 may be a potential therapeutic target for inflammatory diseases. However, the mechanisms via which miR-21 is associated with chronic inflammation require further exploration.

In vivo, miR-21 knockout alters the homeostasis of Ly- $6 C^{\text {lo }}$ cells and reduces the formation of early atherosclerotic lesions in apolipoprotein E knockout mice (26), while in low-density lipoprotein receptor knockout mice, miR-21 knockout leads to inflammatory cell accumulation, defects in efferocytosis and accelerated development of advanced atherosclerosis (25). Furthermore, miR-21 knockout exacerbates angiotensin II-induced thoracic aortic aneurysm and dissection formation in mice, which may be associated with the TGF- $\beta$ /SMAD3 signaling pathway (27). However, Li et al (28) reported that miR-21 suppresses PTEN, and activates MMP-2 and MMP-9 to promote the proliferation and migration of cells located within an aortic aneurysm in rats. Collectively, these results suggest that miR-21 exerts an intricate role in chronic vascular inflammatory response, which may be a key mediator of GEN in inhibiting VEC damage.

Our previous studies reported that GEN and its derivative can protect against lysophosphatidylcholine-induced VEC injury, inhibit macrophage foaming, reduce VSMC proliferation and migration, and inhibit the angiogenesis of HL-60 cells via the Toll-like receptor 4 signaling pathway (29-31). The present study was designed to investigate the effects and molecular mechanisms of GEN on chronic vascular inflammatory response by stimulating C57BL/6 mice and human umbilical vein (HUV) ECs with LPS.

\section{Materials and methods}

Reagents and antibodies. GEN (purity, $\geq 99 \%$ ) was purchased from Sigma-Aldrich (Merck KGaA). LPS (purity, $\geq 99 \%$ ) was purchased from Beijing Solarbio Science \& Technology Co., Ltd. miR-21 antagomir, miR-21 mimic, miR-21 inhibitor and riboFECT CP were purchased from Guangzhou RiboBio Co., Ltd. FBS, RPMI-1640, PBS and penicillin/streptomycin were purchased from Biological Industries. HiScript ${ }^{\circledR}$ II RT SuperMix for qPCR (+ gDNA wiper), miRNA 1st Strand cDNA Synthesis kit (by stem-loop) and AceQ ${ }^{\circledR}$ qPCR SYBR Green Master Mix were obtained from Vazyme Biotech Co., Ltd. Antibodies against iNOS (cat. no. AF0199), NF- $\kappa$ B p65 (cat. no. AF0874) and $\beta$-actin (cat. no. T0022) were purchased from Affinity Biosciences. Goat anti-mouse HRP-conjugated IgG (cat. no. cW0102S) and goat anti-rabbit HRP-conjugated IgG (cat. no.cW0156S) were acquired from CoWin Biosciences. Rabbit two-step detection kits (cat. nos. PV9001 and PV9002), goat serum and DAB staining solution were all purchased from Beijing Zhongshan Golden Bridge Biotechnology Co., Ltd.

Animals and treatments. A total of $50 \mathrm{C} 57 \mathrm{BL} / 6$ mice

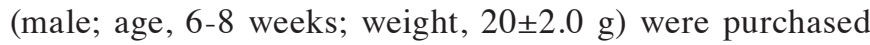
from Hunan SJA Laboratory Animal Co., Ltd. (certificate no. 43004700059037). All mice were housed in a specific pathogen-free laboratory environment under a controlled temperature $\left(20-24^{\circ} \mathrm{C}\right)$ and humidity $(50-60 \%)$ with a $12: 12-\mathrm{h}$ light/dark cycle and ad libitum access to food and water. During the study, parameters indicating the general condition of mice were observed daily, including fur brightness, food and water intake, defecation and behavior. Furthermore, body weight was measured each week. The experimental protocol was approved by the Ethics Committee of Hunan Normal University.

A high-fat diet (10\% lard, $10 \%$ egg yolk powder, $2 \%$ cholesterol and $0.2 \%$ cholic acid) combined with LPS (intraperitoneal injection) was used to establish a model of chronic vascular inflammation in mice (32-34). After 1 week of acclimatization, mice were randomly divided into 5 groups ( $\mathrm{n}=10 /$ group): Control group; LPS group; LPS + GEN group; LPS + GEN + miR-21 negative control (NC) group; and LPS + GEN + miR-21 Antagomir group (Fig. 1). LPS and $0.9 \% \mathrm{NaCl}(2 \mathrm{mg} / \mathrm{kg} / 2$ days, IP injection) and $\mathrm{GEN}$ and $0.9 \% \mathrm{NaCl}(10 \mathrm{mg} / \mathrm{kg} /$ day, intragastric infusion) were administered to mice from the first week to the end of experiment. miR-21 NC, miR-21 antagomir and $0.9 \% \mathrm{NaCl}$ ( $25 \mathrm{mg} / \mathrm{kg} / 3$ days) were injected into the tail vein beginning in the week 17 until the end of week 20. After 20 weeks, mice were anesthetized with an intraperitoneal injection of pentobarbital sodium $(40 \mathrm{mg} / \mathrm{kg})$ and then sacrificed via cervical dislocation; their aortas were dissected and fixed in $4 \%$ paraformaldehyde (PFA) for $2 \mathrm{~h}$ at room temperature for immunohistochemistry (IHC) or frozen at $-80^{\circ} \mathrm{C}$ for reverse transcription-quantitative (RT-q)PCR and western blot analyses.

Cells and transfection. The HUVEC cell line HUVE-12 was supplied by China Center for Type Culture Collection and routinely cultured in RPMI-1640 with $10 \%$ fetal bovine serum (FBS), 1,000 U/ml penicillin and $100 \mathrm{U} / \mathrm{ml}$ streptomycin at $5 \% \mathrm{CO}_{2}$ and $37^{\circ} \mathrm{C}$.

HUVE-12 cells $\left(5 \times 10^{4} / \mathrm{ml}\right)$ were seeded on 6-well plates and cultured for $24 \mathrm{~h}$ at $37^{\circ} \mathrm{C}$ with $5 \% \mathrm{CO}_{2}$. Cell density at the time of transfection was $30-50 \%$. Subsequently, miR-21 mimic 


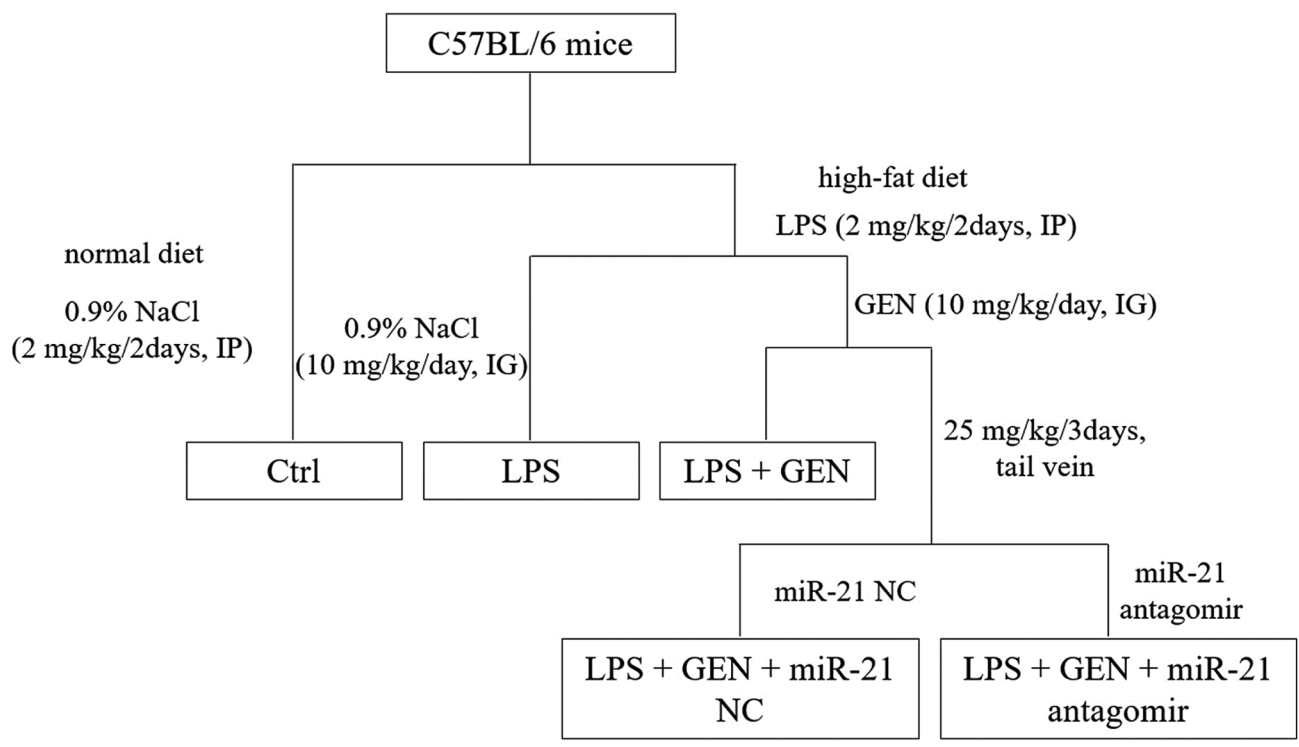

Figure 1. Flowchart of the animal study. LPS, $0.9 \% \mathrm{NaCl}$ and GEN were administered to mice throughout the duration of the experiment. miR-21 NC and miR-21 antagomir were injected into the tail vein, beginning in week 17 until the end of week 20. Ctrl, control; GEN, genistein; IG, intragastric; IP, intraperitoneal; LPS, lipopolysaccharide; miR, microRNA; NC, negative control.

(50 nM), mimic NC (50 nM), miR-21 inhibitor (100 nM) and inhibitor NC (100 nM) were transfected into cells using riboFECT $^{\text {тм }} \mathrm{CP}$ according to the manufacturer's protocol. At $24 \mathrm{~h}$ after transfection, RT-qPCR was used to detect the transfection efficiency. After $48 \mathrm{~h}$, cells were pretreated with GEN (10 $\mu \mathrm{mol} / \mathrm{l})$ for $2 \mathrm{~h}$, and then incubated with LPS $(1 \mu \mathrm{g} / \mathrm{ml})$ for a further $24 \mathrm{~h}$.

$R T-q P C R$. Total RNA were isolated from aorta and HUVE-12 cells using TRIzol ${ }^{\circledR}$ (Vazyme Biotech Co., Ltd.) reagent according to the manufacturer's protocol. Tissue $(100 \mathrm{mg})$ in $1 \mathrm{ml} \mathrm{TRIzol}{ }^{\circledR}$ was placed in a grinder, and cells $\left(10 \mathrm{~cm}^{2}\right.$ area) were lysed with $1 \mathrm{ml} \mathrm{TRIzol}{ }^{\circledR}$. The purity and concentration of RNA were measured using a microplate reader with a multi-wavelength measurement system. Next, RNA was reverse transcribed into cDNA using a HiScript Q RT SuperMix for qPCR Kit (+ gDNA wiper) or miRNA 1st Strand cDNA Synthesis Kit (by stem-loop) according to the manufacturer's protocol. qPCR was conducted using AceQ qPCR SYBR Green Master Mix. The following thermocycling conditions were used for qPCR: Initial denaturation at $95^{\circ} \mathrm{C}$ for $10 \mathrm{~min}$; formal denaturation at $95^{\circ} \mathrm{C}$ for $10 \mathrm{sec}$; 40 cycles of $30 \mathrm{sec}$ at $60^{\circ} \mathrm{C}$ and $15 \mathrm{sec}$ at $95^{\circ} \mathrm{C}$; and final extension for $60 \mathrm{sec}$ at $60^{\circ} \mathrm{C}$ and $15 \mathrm{sec}$ at $95^{\circ} \mathrm{C}$. RNA expression was analyzed using the $2^{-\Delta \Delta \mathrm{Cq}}$ method (35). The mRNA expression levels of TNF- $\alpha$ and IL-6 in mice were normalized to $18 \mathrm{~S}$, TNF- $\alpha$, IL- 6 and iNOS in HUVE-12 cells were normalized to GAPDH, and miR-21 gene expression was normalized to U6. Primer sequences are listed in Table I.

Western blotting. Total protein was extracted from aorta and HUVE-12 cells using RIPA buffer (Beijing ComWin Biotech Co.); the protein concentration was determined using a BCA protein assay kit (Beyotime Institute of Biotechnology). Protein lysates $(20 \mu \mathrm{g})$ were separated via $10 \%$ SDS-PAGE and transferred onto PVDF membranes, which were then blocked in
$5 \%$ non-fat milk for $1 \mathrm{~h}$ at room temperature. Next, membranes were incubated at $4^{\circ} \mathrm{C}$ overnight with primary antibodies against NF- $\kappa$ B p65 $(1: 2,000)$, iNOS $(1: 3,000)$ and $\beta$-actin (1:5,000). After being washed with PBST (0.05\% Tween-20), blots were incubated at room temperature for $2 \mathrm{~h}$ with goat anti-rabbit HRP-conjugated antibody $(1: 10,000)$ or goat anti-mouse HRP-conjugated antibody $(1: 10,000)$, followed by visualization using ECL Western Blotting Substrate (NCM Biotech Co., Ltd) detection. The protein levels were quantified using Image-Pro Plus software (version 6.0; Media Cybernetics, Inc.).

IHC. Paraffin-embedded sections (4-6 $\mu \mathrm{m})$ were incubated in an oven at $60^{\circ} \mathrm{C}$ for $1 \mathrm{~h}$, then immersed in xylene for $10 \mathrm{~min}$, anhydrous ethanol for $5 \mathrm{~min}, 95 \%$ alcohol for $3 \mathrm{~min}$, $85 \%$ alcohol for $3 \mathrm{~min}$ and $75 \%$ alcohol for $3 \mathrm{~min}$ prior to rinsing with water for $3 \mathrm{~min}$, all performed at room temperature. Later, EDTA ( $\mathrm{pH}$ 9.0) was used to retrieve antigens and $20 \% \mathrm{H}_{2} \mathrm{O}_{2}$ was used to block endogenous peroxidase activity at room temperature for $20 \mathrm{~min}$. After blocking with $5 \%$ goat serum (Beijing Solarbio Science \& Technology Co., Ltd.) for $1 \mathrm{~h}$ at room temperature, sections were incubated with anti-NF- $\kappa$ B p65 antibody (1:200) overnight at $4^{\circ} \mathrm{C}$. Polymer Helper (cat. no. PV-9001) and Poly Peroxidase-anti-rabbit IgG (cat. no. PV-9002) were applied for $30 \mathrm{~min}$ at room temperature in sequence. Finally, counterstaining was performed using hematoxylin for $5 \mathrm{~min}$ at room temperature and DAB were used to develop protein expression, respectively. Stained samples were visualized in three fields of view using a light microscope (Olympus Corporation; magnification, x400) and analyzed by Image-Pro Plus software.

Immunofluorescence (IF). Sections were blocked with 5\% goat serum at room temperature for $1 \mathrm{~h}$, then incubated with anti-NF- $\kappa$ B p65 antibody (1:100) at $4^{\circ} \mathrm{C}$ overnight, followed by DyLight $^{\mathrm{TM}} 594$ goat anti-rabbit IgG (1:1,000; cat. no. A23430; 


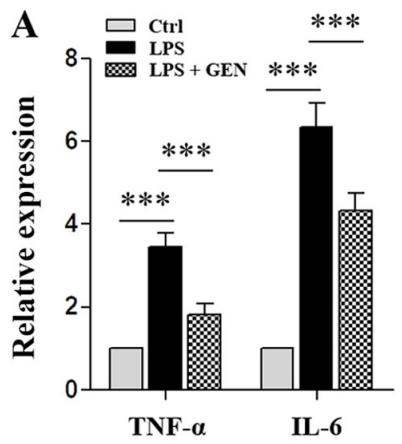

C

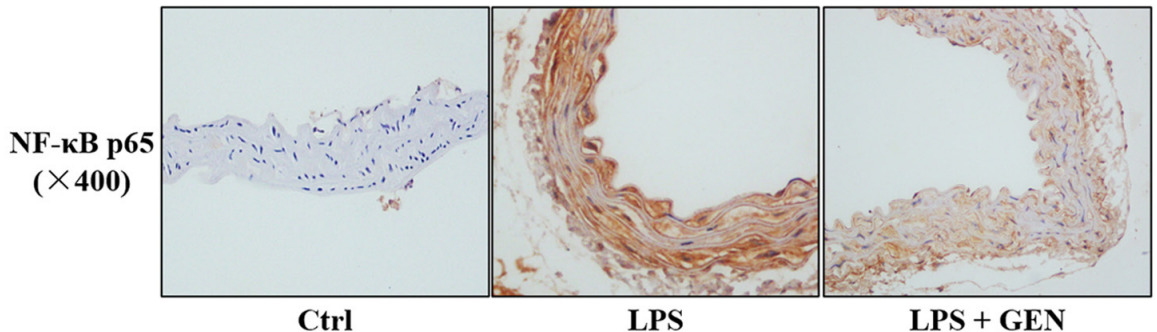

D
B

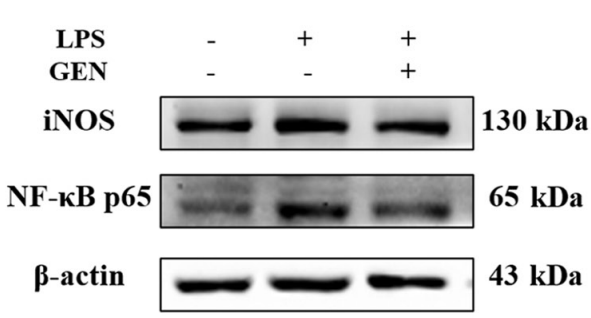

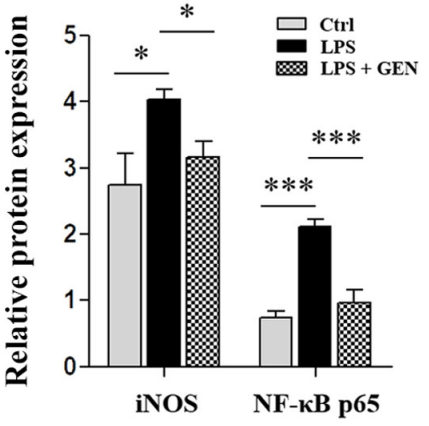

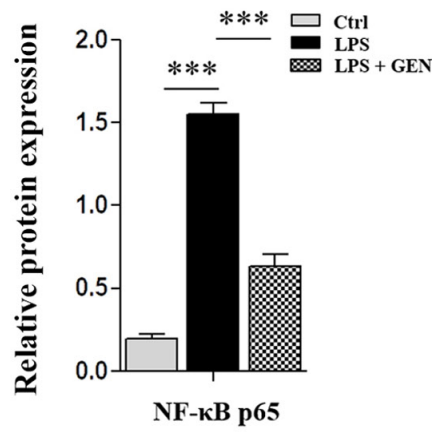

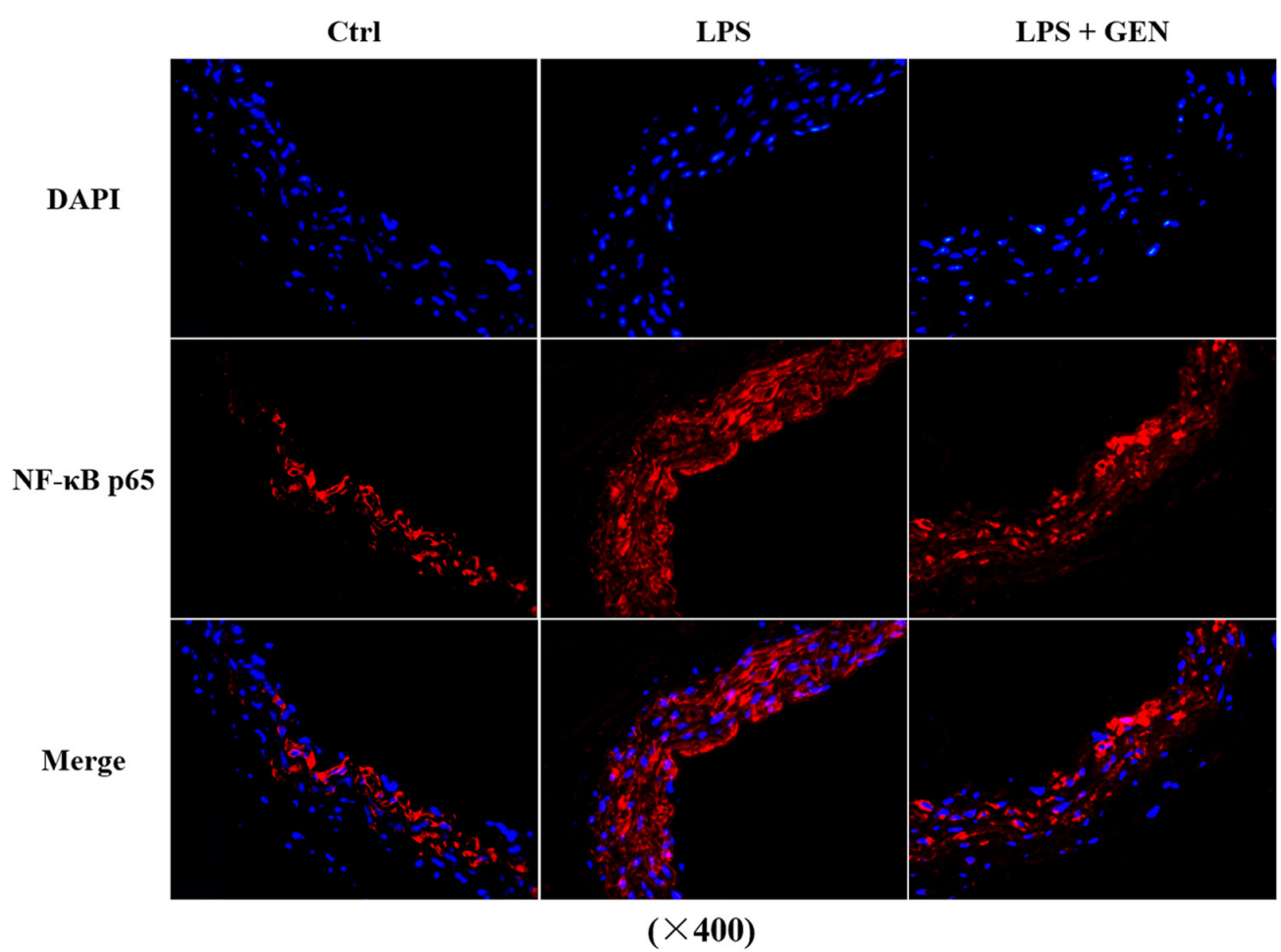

Figure 2. Effects of GEN on chronic inflammation in the aortae of LPS-treated C57BL/6 mice. (A) Reverse transcription-quantitative PCR analysis of TNF- $\alpha$ and IL-6 mRNA expression. (B) Western blot analysis of the protein levels of iNOS and NF-kB p65. (C) Immunohistochemistry and (D) immunofluorescence staining for NF- $\mathrm{kB}$ p65 (magnification, $\mathrm{x} 400$ ). Data are presented as the mean $\pm \mathrm{SD}(\mathrm{n}=10 / \mathrm{group})$. ${ }^{*} \mathrm{P}<0.05,{ }^{* * *} \mathrm{P}<0.001$. Ctrl, control; GEN, genistein; iNOS, inducible nitric oxide synthase; LPS, lipopolysaccharide.

Abbkine Scientific Co., Ltd.) for $2 \mathrm{~h}$ at room temperature in the dark. Finally, DAPI was used to stain the nuclei for $10 \mathrm{~min}$ at room temperature. Stained sections were visualized in three fields of view using a fluorescence microscope (magnification, $\mathrm{x} 400$ ).

In vitro, HUVE-12 cells $\left(3 \times 10^{5} / \mathrm{ml}\right)$ were seeded onto coverslips. After 24 h, the cells were pretreated with GEN
$(10 \mu \mathrm{M})$ for $2 \mathrm{~h}$ prior to co-incubation with LPS $(1 \mu \mathrm{g} / \mathrm{ml})$ for $24 \mathrm{~h}$ at $37^{\circ} \mathrm{C}$, then fixed with $4 \%$ PFA for $10 \mathrm{~min}$ at room temperature. Subsequently, cells were permeabilized by $0.2 \%$ Triton- 100 for 5 min and blocked with 5\% goat serum for $1 \mathrm{~h}$ at room temperature. All subsequent steps were performed as described for tissue sections; images were observed via fluorescence microscopy (magnification, x400). 
Table I. Primer sequences.

\begin{tabular}{|c|c|}
\hline Gene & Primer sequence $\left(5^{\prime}-3^{\prime}\right)$ \\
\hline $18 \mathrm{~S}$ & $\begin{array}{ll}\text { F: } & \text { AGTCCCTGCCCTTTGTACACA } \\
\text { R: } & \text { CGATCCGAGGGCCTCACTA }\end{array}$ \\
\hline$m m u-\mathrm{TNF}-\alpha$ & $\begin{array}{l}\text { F: CAAGGGACAAGGCTGCCCCG } \\
\text { R: GCAGGGGCTCTTGACGGCAG }\end{array}$ \\
\hline$m m u$-IL-6 & $\begin{array}{ll}\text { F: } & \text { AACGATGATGCACTTGCAGA } \\
\text { R: } & \text { CTCTGAAGGACTCTGGCTTTG }\end{array}$ \\
\hline GAPDH & $\begin{array}{ll}\text { F: } & \text { CAGGAGGCATTGCTGATGAT } \\
\text { R: } & \text { GAAGGCTGGGGCTCATTT }\end{array}$ \\
\hline$h s a-\mathrm{TNF}-\alpha$ & $\begin{array}{l}\text { F: CGTGGAGCTGGCCGAGGAG } \\
\text { R: AGGAAGGAGAAGAGGCTGAGGAAC }\end{array}$ \\
\hline hsa-IL-6 & $\begin{array}{ll}\text { F: } & \text { ATTCAATGAGGAGACTTGCCTGGTG } \\
\text { R: } & \text { ATCTGCACAGCTCTGGCTTGTTC }\end{array}$ \\
\hline$h s a$-iNOS & $\begin{array}{ll}\text { F: } & \text { GGGACCCGCACCACTACA } \\
\text { R: } & \text { CTGGATGTCGGACTTTGTAGATT }\end{array}$ \\
\hline $\operatorname{miR}-21$ & $\begin{array}{ll}\text { RT: GTCGTATCCAGTGCAGGGTCCGAG } \\
\text { GTATTCGCACTGGATACGACTCAACA } \\
\text { F: } \\
\text { R: } & \text { GCCGCAGGGTCCGAGGT } \\
& \end{array}$ \\
\hline U6 & $\begin{array}{l}\text { RT: AAAATATGGAACGCTTCACGAATTT } \\
\text { F: CTCGCTTCGGCAGCACA } \\
\text { R: AACGCTTCACGAATTTGCGT }\end{array}$ \\
\hline
\end{tabular}

F, forward; R, reverse; RT, reverse transcription; mmu, Mus musculus; hsa, Homo sapiens; iNOS, inducible nitric oxide synthase.

Statistical analysis. Data are presented as the mean \pm SD. SPSS 20.0 (IBM Corp.) and GraphPad Prism 7.0 (GraphPad Software, Inc.) were used for data analysis. Student's t-test was used for statistical comparisons between two groups. One-way ANOVA was used for comparisons among multiple groups, followed by LSD or Bonferroni post hoc tests with equal variance and Dunnett's T3 with unequal variance. $\mathrm{P}<0.05$ (or $\mathrm{P}<0.003$ with Bonferroni correction) was considered to indicate a statistically significant difference.

\section{Results}

GEN attenuates the expression of inflammation-associated factors in the aortae of LPS-treated mice. LPS is a main component of the cell wall in Gram-negative bacteria (36) and has been demonstrated to be one of the pathogenic factors in chronic vascular inflammation (37). In the present study, it was demonstrated that intraperitoneal injection of LPS significantly increased the mRNA expression of TNF- $\alpha$ and IL- 6 and the protein levels of iNOS and NF- $\kappa$ B p65 in the vasculature of mice $(\mathrm{P}<0.05$; Fig. $2 \mathrm{~A}$ and $\mathrm{B})$. In addition, the relative protein expression of $\mathrm{NF}-\kappa \mathrm{B}$ p65 increased $\sim 6$-fold in aorta from LPS-treated mice $(\mathrm{P}<0.001$; Fig. 2C and D). These results indicated that a mouse model of chronic vascular inflammatory response was successfully established.

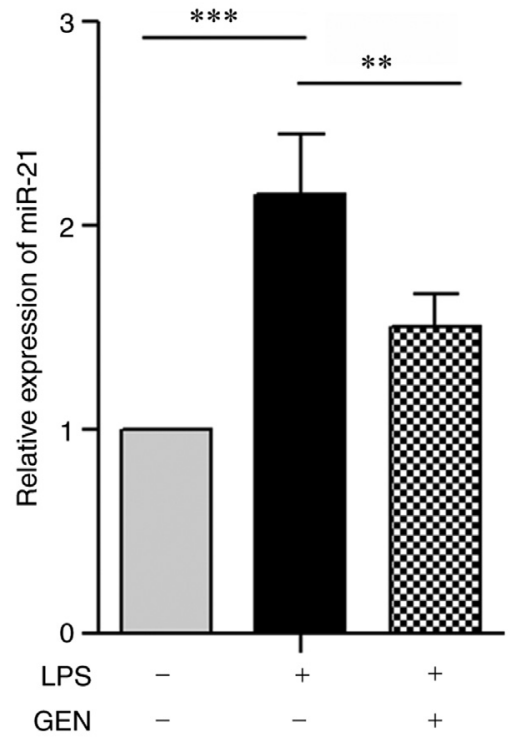

Figure 3. Effects of GEN on miR-21 expression in the aortae of LPS-treated mice. Reverse transcription-quantitative PCR detected the expression of miR-21. Data are presented as the mean $\pm \mathrm{SD}$ ( $\mathrm{n}=10$ /group). ${ }^{* *} \mathrm{P}<0.01$, ${ }^{* * * *} \mathrm{P}<0.001$. GEN, genistein; LPS, lipopolysaccharide; miR, microRNA.

Furthermore, it was revealed that intragastric administration of GEN significantly reduced the mRNA expression of TNF- $\alpha$ and IL- 6 in LPS-treated animals, as well as iNOS and $\mathrm{NF}-\kappa \mathrm{B}$ p 65 protein levels $(\mathrm{P}<0.05$; Fig. $2 \mathrm{~A}$ and $\mathrm{B})$. After administration of GEN, NF- $\kappa \mathrm{B}$ p 65 staining was significantly reduced by $\sim 50 \%$ in LPS-treated mice $(\mathrm{P}<0.001$; Fig. 2C and D). Collectively, these data indicated that GEN inhibited chronic inflammation in blood vessels.

GEN suppresses miR-21 expression in the aortae of $L P S$-treated mice. In atherosclerosis, aberrantly upregulated expression miR-21 in the aorta has been independently associated with the pathogenesis of chronic vascular inflammation (38). RT-qPCR is currently the most convenient and popular method for detecting miRNA expression (39) and was used to measure miR-21 expression in aortic tissue in the present study. It was revealed that intraperitoneal injection of LPS significantly stimulated miR-21 expression by $\sim 2$.1-fold in $\mathrm{C} 57 \mathrm{BL} / 6$ mice $(\mathrm{P}<0.001$; Fig. 3). Additionally, co-treatment with GEN significantly suppressed miR-21 expression, which was reduced by $\sim 30 \%$ ( $\mathrm{P}<0.01$; Fig. 3).

miR-21 antagomir promotes the inhibitory effects of GEN on inflammation-associated factor expression in the aortae of LPS-treated mice. In vivo, miRNA antagomirs pass through the cell membrane, and inhibit the activity of their target miRNAs (40); thus, they are frequently used for miRNA silencing. To evaluate the effects of miR-21 on GEN, LPS-treated mice were injected with miR-21 antagomir through the tail vein. Compared with miR-21 NC, miR-21 antagomir significantly decreased the levels of miR-21, TNF- $\alpha$ and IL-6 ( $<<0.01$; Fig. 4A), and the protein levels of iNOS and NF- $\kappa$ B p65 $(\mathrm{P}<0.05$; Fig. 4B) in mice treated with LPS + GEN. Furthermore, IHC and IF results indicated that $\mathrm{NF}-\kappa \mathrm{B}$ p 65 protein changes were consistent with the western blot analysis $(\mathrm{P}<0.001$; Fig. $4 \mathrm{C}$ and $\mathrm{D})$. 


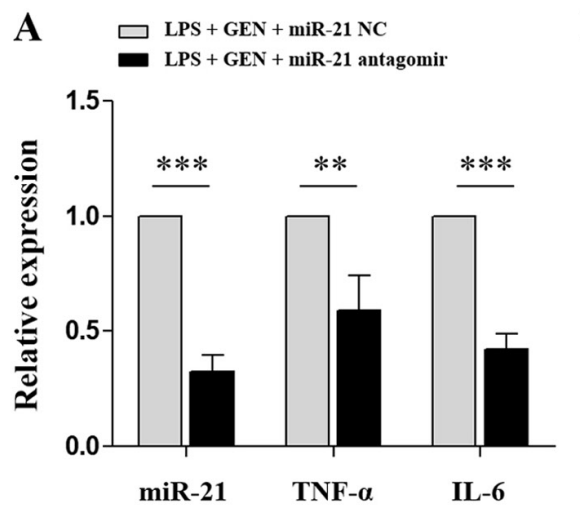

C

$\mathrm{NF}-\mathrm{\kappa B}$ p65 $(\times 400)$

LPS + GEN + miR-21 NC

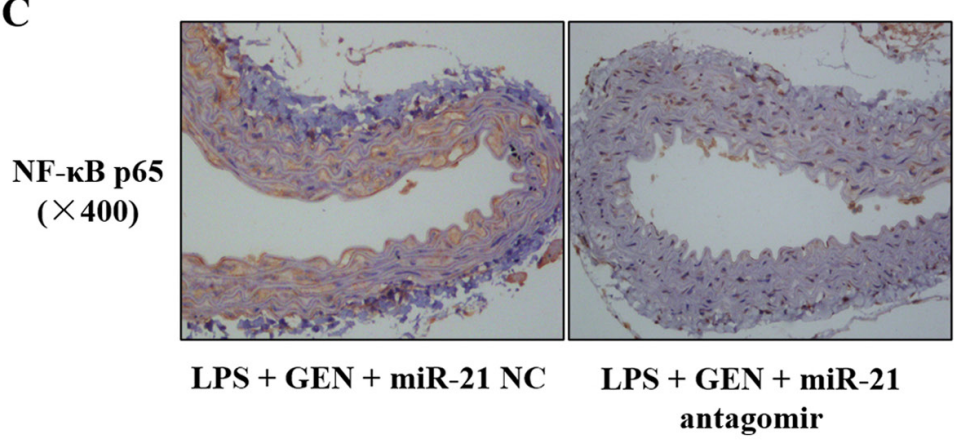

B

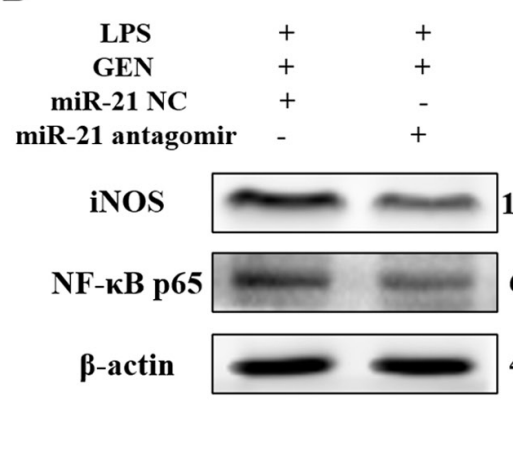

$\square$ LPS + GEN + miR-21 NC

- LPS + GEN + miR-21 antagomir

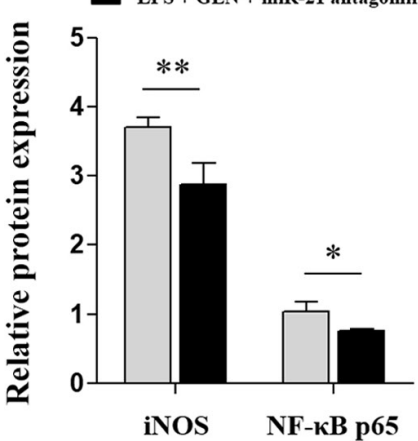

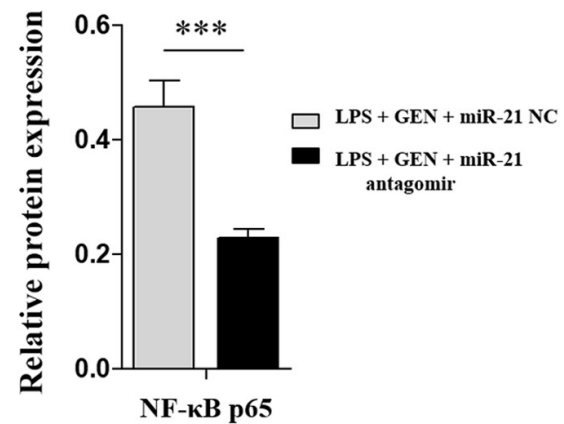

D

DAPI

NF- $\mathrm{kB}$ p65

Merge

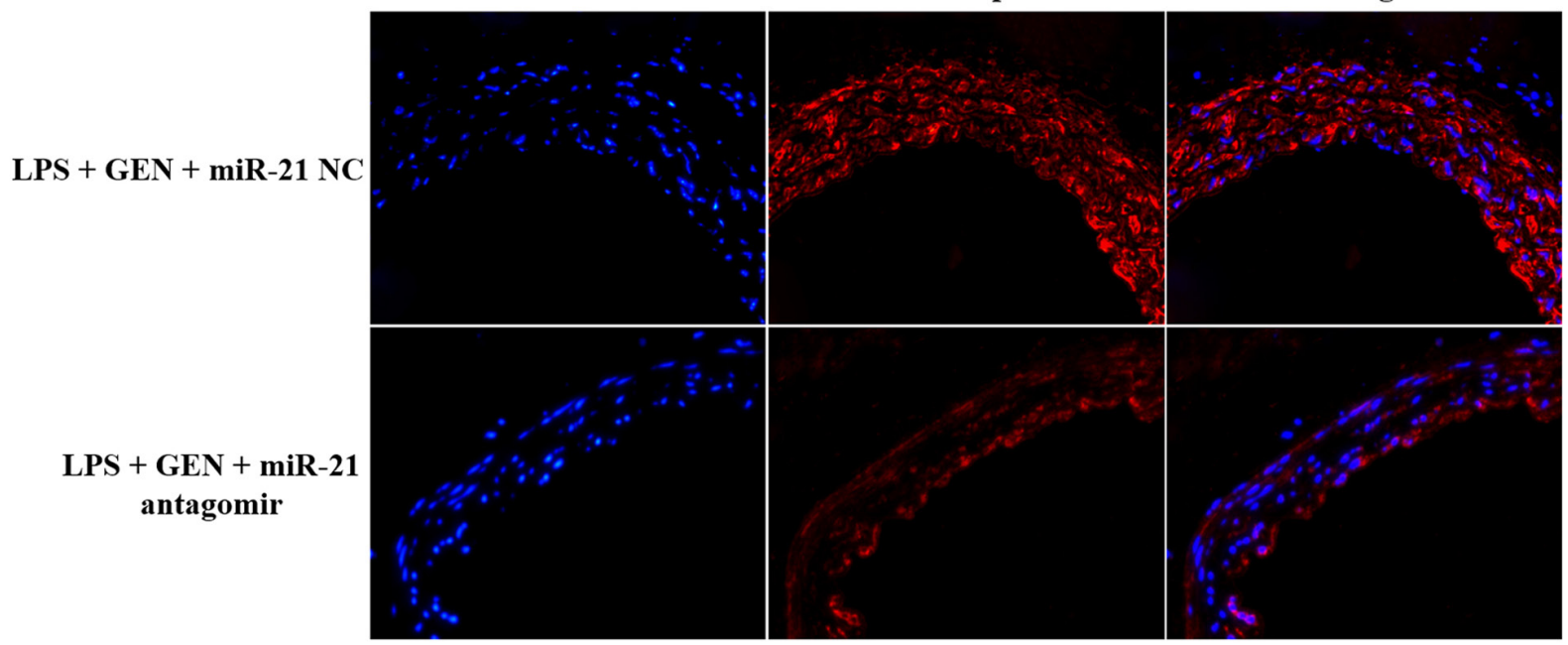

$(\times 400)$

Figure 4. Effects of miR-21 antagomir on GEN-mediated inhibition of inflammation-associated factors in the aortae of LPS-treated mice. (A) Reverse transcription-quantitative PCR analysis of miR-21, TNF- $\alpha$ and IL-6 mRNA expression. (B) Western blot analysis of the protein levels of iNOS and NF- $\mathrm{kB}$ p65. (C) Immunohistochemistry and (D) immunofluorescence staining for NF- $\kappa B$ p65 (magnification, $\mathrm{x} 400$ ). Data are presented as the mean $\pm \mathrm{SD}$ ( $\mathrm{n}=10 / \mathrm{group}$ ). ${ }^{*} \mathrm{P}<0.05,{ }^{* *} \mathrm{P}<0.01,{ }^{* * *} \mathrm{P}<0.001$. GEN, genistein; iNOS, inducible nitric oxide synthase; LPS, lipopolysaccharide; miR, microRNA; NC, negative control.

These results suggested that miR-21 served an important role in the GEN-mediated attenuation of inflammation. Based on these findings, it was hypothesized that GEN inhibited chronic vascular inflammation by regulating miR-21.

miR-21 mimic attenuates GEN-mediated inhibition of inflammation in LPS-treated VECs. ECs in arteries serve an important role in anti-atherosclerotic processes due to unidentified pathways (41). EC damage is a major initial trigger for chronic vascular inflammation (42). Therefore, an inflammatory response model was constructed in HUVE-12 cells using LPS $(1 \mu \mathrm{g} / \mathrm{ml} ; 24 \mathrm{~h})$ in vitro in combination with miR-21 mimic transfection. RT-qPCR revealed that miR-21 mimic significantly upregulated miR-21 expression 2-fold in HUVE-12 cells $(\mathrm{P}<0.001$; Fig. 5A). LPS increased TNF- $\alpha$, IL-6 and iNOS mRNA expression, and iNOS and NF- $\mathrm{B}$ p 65 protein expression in cells transfected with mimic NC (Fig. 5B-D), which indicated that the inflammation model was successfully established in vitro. Furthermore, it was demonstrated that 
A

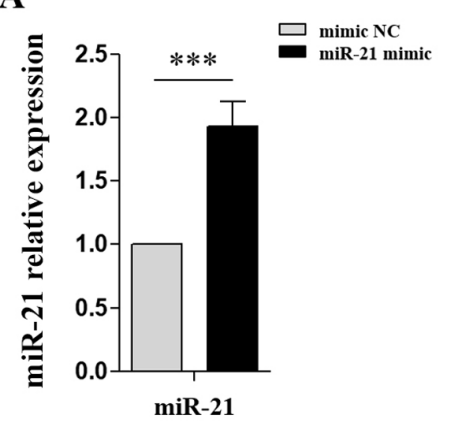

B TNF- $a$

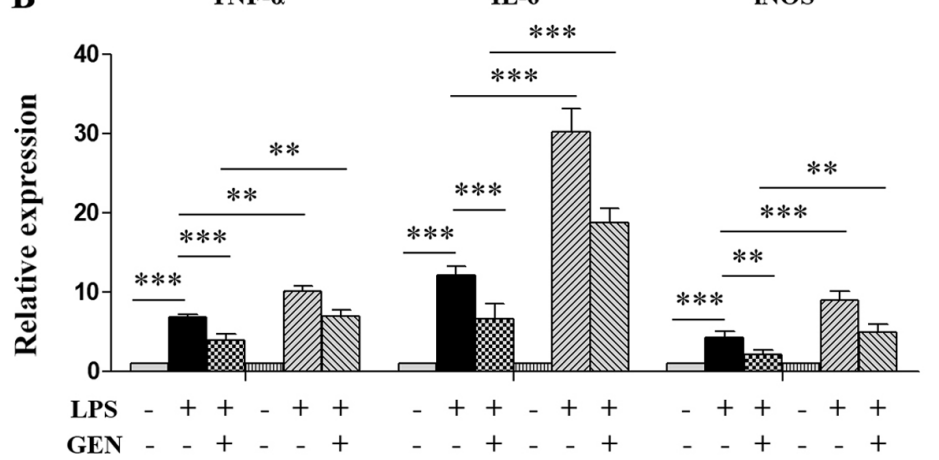

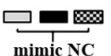

血四

C
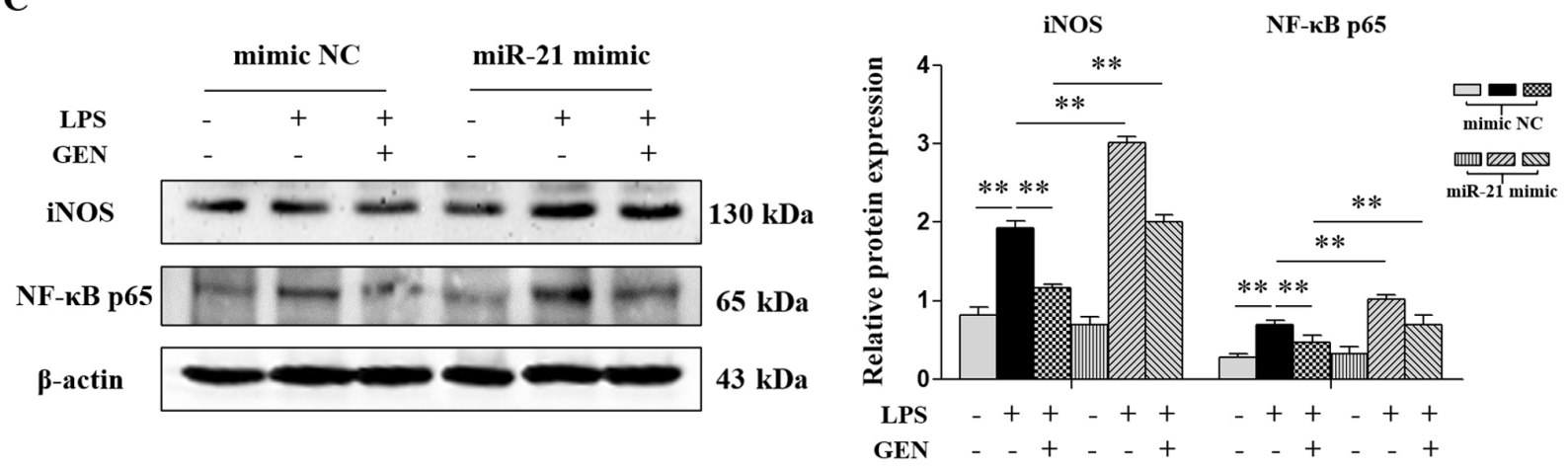

D

\begin{tabular}{ccc}
\multicolumn{3}{c}{ mimic NC } \\
\hline Ctrl & LPS & LPS + GEN
\end{tabular}
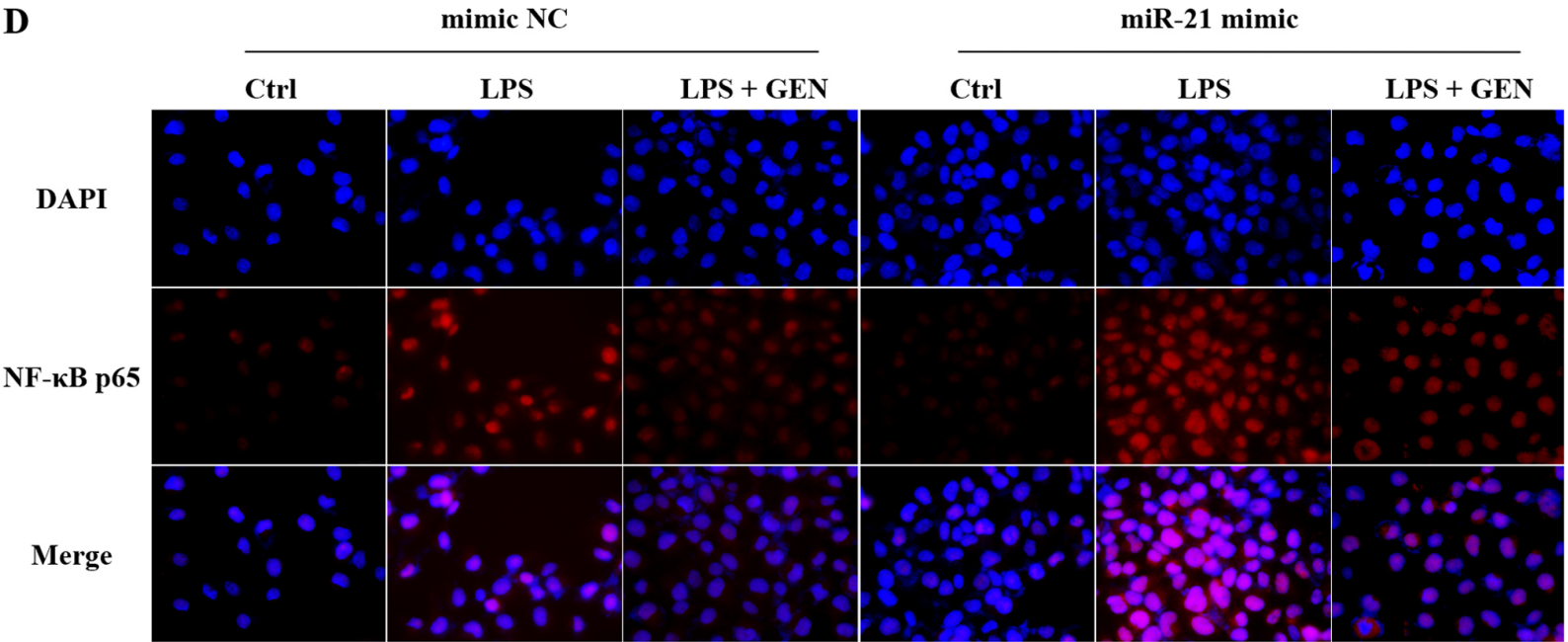

$(\times 400)$

Figure 5. Effects of miR-21 mimic on GEN-mediated inhibition of the expression of inflammation-associated factors in LPS-treated HUVE-12 cells. After transfection with miR-21 mimic, HUVE-12 cells were pretreated with GEN $(10 \mu \mathrm{mol} / 1)$ for $2 \mathrm{~h}$ and then stimulated with LPS $(1 \mu \mathrm{g} / \mathrm{ml})$ for another $24 \mathrm{~h}$. (A) RT-qPCR analysis of miR-21 expression. (B) RT-qPCR analysis of TNF- $\alpha$, IL-6 and iNOS mRNA expression. (C) Western blot analysis of the protein

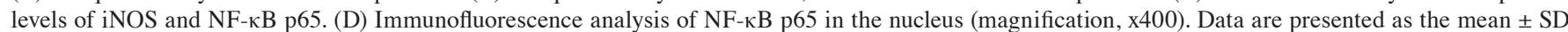
of three independent experiments. ${ }^{* *} \mathrm{P}<0.003,{ }^{* * * *} \mathrm{P}<0.001$. GEN, genistein; iNOS, inducible nitric oxide synthase; LPS, lipopolysaccharide; miR, microRNA; RT-qPCR, reverse transcription-quantitative PCR; Ctrl, control.

GEN decreased TNF- $\alpha$, IL- 6 and iNOS mRNA expression, and iNOS and NF-kB p65 protein levels in LPS-treated VECs; however, miR-21 mimic significantly promoted the expression of these factors, attenuating the inhibitory effects of GEN on inflammation (Fig. 5B-D).

miR-21 inhibitor promotes the GEN-mediated inhibition of inflammation in LPS-treated VECs. Additionally, miRNA inhibitors, which are chemically modified complementary single strands to mature miRNA, were used to silence miR-21. The results revealed that miR-21 was downregulated by $\sim 60 \%$ in HUVE-12 cells after transfection with miR-21 inhibitor $(\mathrm{P}<0.001$; Fig. 6A). Both GEN and miR-21 inhibitor decreased the mRNA expression of TNF- $\alpha$, IL-6 and iNOS, and the protein levels of iNOS and NF- $\kappa \mathrm{B}$ p65 in LPS-treated VECs, and miR-21 inhibitor enhanced the effects of GEN on inflammation-associated factor expression (Fig. 6B-D). 
A

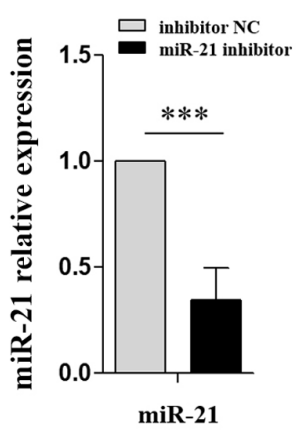

B

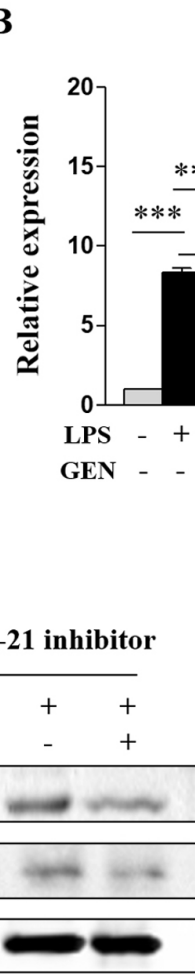

TNF- $\alpha$

L-6

iNOS

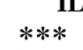

$\underline{* * *} * * *$

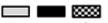

inhibitor NC

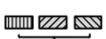

miR-21 inhibito

C

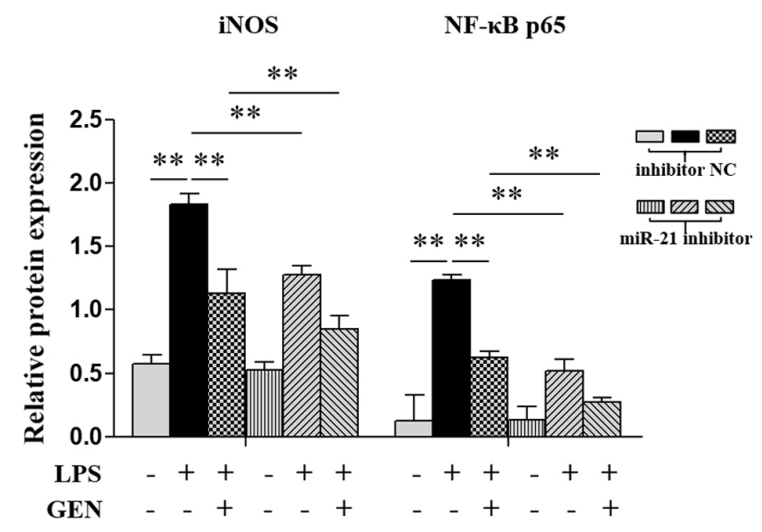

D

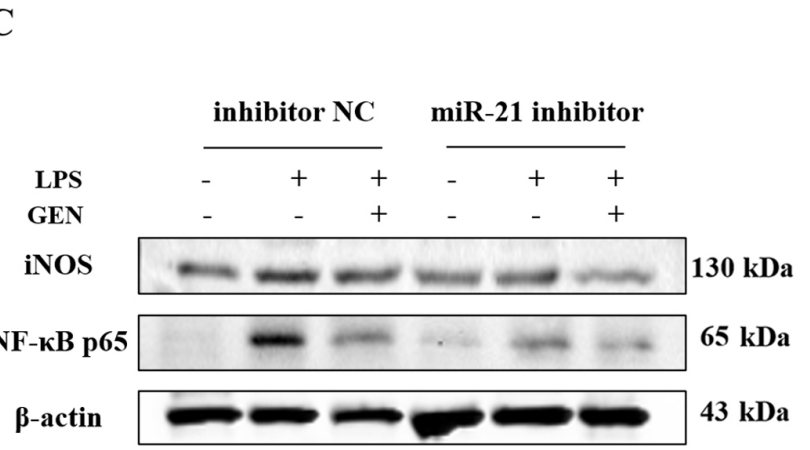

inhibitor NC

miR-21 inhibitor

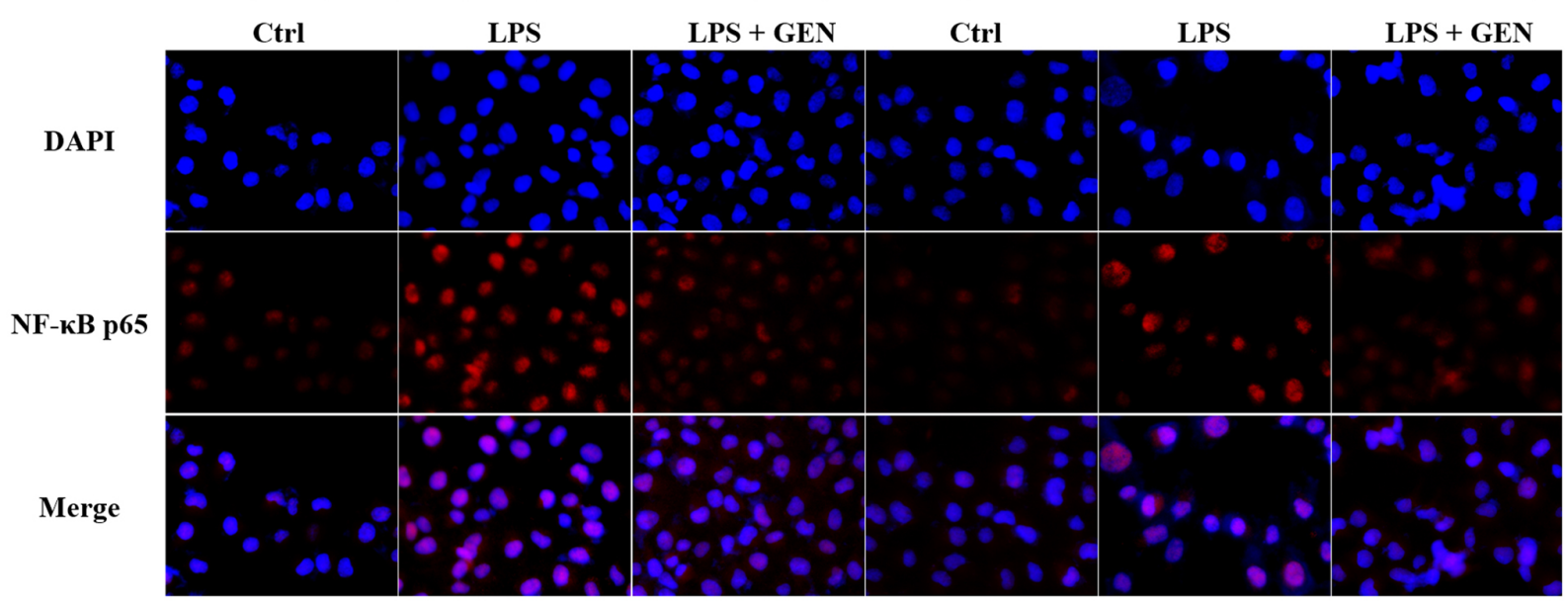

$(\times 400)$

Figure 6. Effects of miR-21 inhibitor on GEN-mediated inhibition of the expression of inflammation-associated factors in LPS-treated HUVE-12 cells. After transfection with miR-21 inhibitor, HUVE-12 cells were pretreated with GEN (10 $\mu \mathrm{mol} / \mathrm{l})$ for $2 \mathrm{~h}$ and then stimulated with LPS $(1 \mu \mathrm{g} / \mathrm{ml})$ for another $24 \mathrm{~h}$. (A) RT-qPCR analysis of miR-21 expression. (B) RT-qPCR analysis of TNF- $\alpha$, IL-6 and iNOS mRNA expression. (C) Western blot analysis of the protein

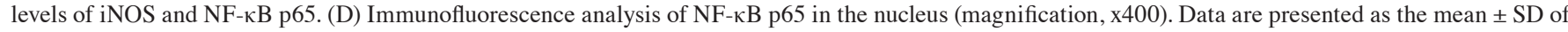
three independent experiments. ${ }^{* *} \mathrm{P}<0.003,{ }^{* * * *} \mathrm{P}<0.001$. miR, microRNA; GEN, genistein; LPS, lipopolysacchride; RT-qPCR, reverse transcription-quantitative PCR; Ctrl, control.

\section{Discussion}

Cardiovascular disease is a serious disease affecting human health, and cases of mortality are projected to increase from 16.7 million in 2002 to 23.3 million in 2030 worldwide (43). Chronic vascular inflammation is an important pathological basis of cardiovascular disease; further research into its etiology, pathogenesis and prevention will help to delay or reverse its progression, and reduce the morbidity and mortality of cardiovascular disease.

Inflammation is a natural and adaptive process to noxious stimuli that the body is constantly exposed to $(44,45)$, and the vascular response is considered to be the central component of inflammation. Acute inflammation is beneficial to the body, but chronic inflammation can lead to a pathological state (46). LPS, an endotoxin found in the outer layer of the cell wall of 


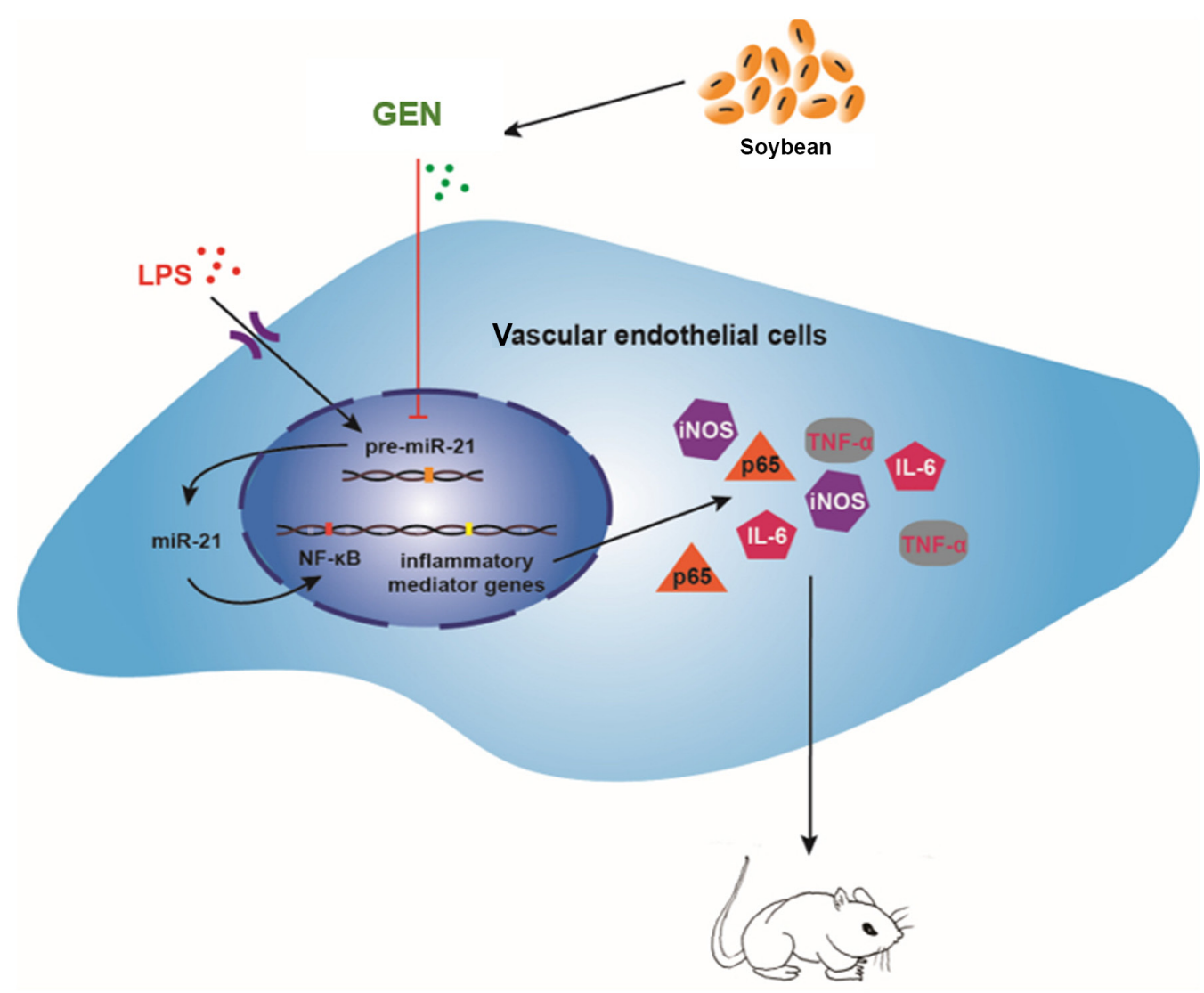

Chronic vascular inflammatory response

Figure 7. Schematic of the proposed signaling pathway via which GEN alleviates chronic vascular inflammatory response in LPS-treated mice. GEN, genistein; iNOS, inducible nitric oxide synthase; LPS, lipopolysaccharide; miR, microRNA.

Gram-negative bacteria, induces inflammatory responses by activating the NF- $\mathrm{KB}$ pathway, which is important for human immune responses (47). Wu et al (48) reported that vascular inflammation stimulated by LPS resulted in atheromatous lesions in vivo. Therefore, chronic inflammation was induced in the aortae of mice via a high-fat diet combined with intraperitoneal injection of LPS. Using this method, a number of inflammatory cytokines and enzymes were upregulated in vascular tissue, including TNF- $\alpha$, IL-6, iNOS and NF- $\mathrm{B}$ p65.

GEN is the major natural isoflavone in soy and soy-based foods (49) and can inhibit inflammation (50), delay aging (51) and prevent senile dementia (52); however, the underlying mechanisms are yet to be fully elucidated. As a potent pro-inflammatory cytokine, $\mathrm{TNF}-\alpha$ participates in early vascular inflammation by upregulating aortic chemokines and adhesion molecules (53). IL-6 is produced by macrophages and $\mathrm{T}$ cells, and is involved in the pathogenesis of several chronic inflammatory diseases (54). Nitric oxide (NO), an important endogenous regulator, is of great relevance for the maintenance of VEC homeostasis (55). iNOS is only expressed under pathological conditions and catalyzes L-arginine to NO, and iNOS is closely associated with vascular inflammation (56). The $\mathrm{NF}-\kappa \mathrm{B}$ family is composed of p65, p50, p52, RelB and c-Rel, which combine to form transcriptionally active dimers (57). After activation, p65 is transported from the cytoplasm to the nucleus. Where it facilitates the transcription of inflammatory cytokines (58). The present findings indicated that GEN downregulated the expression of TNF- $\alpha$, IL-6, iNOS and p65 in LPS-injured aortae and VECs, resulting in the inhibition of chronic inflammation in mouse vascular, meanwhile, GEN also reduced the expression of miR-21 in LPS-injured aortae. Based on these findings, it is hypothesized that GEN inhibits chronic vascular inflammation by downregulating miR-21.

Epigenetics is one of the most popular research fields in the post-genomic era, mainly focusing on non-coding RNA, histone modifications, RNA methylation and DNA methylation (59). miRNAs are non-coding small molecule RNAs (60). It is considered to be of major clinical importance to discover miRNAs and their target genes in the context of inflammation (61). miR-21 is highly expressed in functional cells related to the pathology of cardiovascular disease and regulates inflammation (62). Xue et al (63) found that miR-21 deficiency inhibited the secretion of NF- $\kappa \mathrm{B}$-dependent cytokines in macrophages, such as IL- 6 and TNF- $\alpha$. Therefore, the mechanism via which GEN inhibits chronic vascular inflammation was investigated in the present study by injecting miR-21 antagomir into the tail veins of in mice, and transfecting miR-21 mimic or inhibitor into HUVE-12 cells. The present findings revealed that miR-21 antagomir enhanced GEN-mediated inhibition of chronic inflammatory response in aortae. Furthermore, miR-21 mimic promoted the expression of inflammation-related factors in LPS-treated VECs and attenuated the effects of GEN, whereas miR-21 inhibitor induced opposing effects. 
Although the present study had certain limitations, such as a lack of monitoring liver injury and inflammation, it was still possible to obtain some conclusions. The study provided evidence that GEN inhibited the inflammatory injury of VECs, reduced chronic inflammatory response in the vasculature and effectively improved inflammation, potentially by downregulating miR-21. The mechanism may be closely associated with $\mathrm{NF}-\kappa \mathrm{B}$ p65 (Fig. 7). In subsequent experiments, the interac-

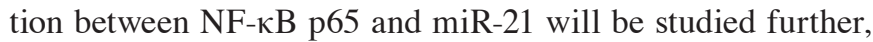
and the pharmacological mechanism via which GEN inhibits chronic vascular inflammation will be elucidated.

\section{Acknowledgements}

Not applicable.

\section{Funding}

This work was supported by grants from Natural Science Foundation of China (grant no. 81370382) and Hunan Provincial Natural Science Foundation of China (grant no. 2020JJ5381).

\section{Availability of data and materials}

The datasets used and/or analyzed during the current study are available from the corresponding author upon reasonable request.

\section{Authors' contributions}

$\mathrm{XX}$ and LC designed the study and wrote the manuscript. SL and LX performed the experiments and analyzed the data. XF conceived the study and wrote the manuscript. XX and LC confirm the authenticity of all the raw data. All authors read and approved the final manuscript.

\section{Ethics approval and consent to participate}

All animal experimental procedures were approved by the Ethics Committee of Hunan Normal University (No. 2018-172).

\section{Patient consent for publication}

Not applicable.

\section{Competing interests}

The authors declare that they have no competing interests.

\section{References}

1. Libby P and Hansson GK: Inflammation and immunity in diseases of the arterial tree: Players and layers. Circ Res 116 307-311, 2015

2. Gimbrone MA Jr and García-Cardeña G: Endothelial cell dysfunction and the pathobiology of atherosclerosis. Circ Res 118: 620-636, 2016.

3. Ross R: Atherosclerosis-an inflammatory disease. N Engl J Med 340: 115-126, 1999.

4. Bacchi S, Palumbo P, Sponta A and Coppolino MF: Clinical pharmacology of non-steroidal anti-inflammatory drugs: A review. Antiinflamm Antiallergy Agents Med Chem 11: 52-64, 2012.
5. LiverTox: Clinical and research information on drug-induced liver injury (Internet). Bethesda (MD) National Institute of Diabetes and Digestive and Kidney Diseases: 31643176, 2012.

6. Harirforoosh S, Asghar W and Jamali F: Adverse effects of nonsteroidal antiinflammatory drugs: An update of gastrointestinal, cardiovascular and renal complications. J Pharm Pharm Sci 16: 821-847, 2013

7. Sutrisno S, Aprina H, Simanungkalit HM, Andriyani A, Barlianto W, Sujuti H, Santoso S, Dwijayasa PM, Wahyuni ES and Mustofa E: Genistein modulates the estrogen receptor and suppresses angiogenesis and inflammation in the murine model of peritoneal endometriosis. J Tradit Complement Med 8: 278-281, 2017.

8. Arakawa S, Inoue M, Kinouchi R, Morizumi S, Yamaguchi M, Shimazu Y and Takeda M: Dietary constituent genistein inhibits the hyperexcitability of trigeminal nociceptive neurons associated with mechanical hyperalgesia following orofacial inflammation. J Oral Biosci 61: 215-220, 2019.

9. Jaiswal N, Akhtar J, Singh SP, Badruddeen and Ahsan F: An overview on genistein and its various formulations. Drug Res (Stuttg) 69: 305-313, 2019.

10. Liu B, Xu L, Yu X, Jiao X, Yan J, Li W and Guo M: Genistein inhibited estradiol-induced vascular endothelial cell injury by downregulating the FAK/Focal adhesion pathway. Cell Physiol Biochem 49: 2277-2292, 2018.

11. Han S, Wu H, Li W and Gao P: Protective effects of genistein in homocysteine-induced endothelial cell inflammatory injury. Mol Cell Biochem 403: 43-49, 2015.

12. Deretic V and Levine B: Autophagy balances inflammation in innate immunity. Autophagy 14: 243-251, 2018.

13. Deretic V and Klionsky DJ: Autophagy and inflammation: A special review issue. Autophagy 14: 179-180, 2018.

14. Zhang H, Yang X, Pang X, Zhao Z, Yu H and Zhou H: Genistein protects against ox-LDL-induced senescence through enhancing SIRT1/LKB1/AMPK-mediated autophagy flux in HUVECs. Mol Cell Biochem 455: 127-134, 2019.

15. Zhang H, Zhao Z, Pang X, Yang J, Yu H, Zhang Y, Zhou H and Zhao J: miR-34a/sirtuin-1/foxo3a is involved in genistein protecting against ox-LDL-induced oxidative damage in HUVECs. Toxicol Lett 277: 115-122, 2017.

16. Yi L, Chang M, Zhao Q, Zhou Z, Huang X, Guo F and Huan J: Genistein-3'-sodium sulphonate protects against lipopolysaccharide-induced lung vascular endothelial cell apoptosis and acute lung injury via BCL-2 signalling. J Cell Mol Med 24: 1022-1035, 2020.

17. Hajibabaie F, Kouhpayeh S, Mirian M, Rahimmanesh I, Boshtam M, Sadeghian L, Gheibi A, Khanahmad H and Shariati L: MicroRNAs as the actors in the atherosclerosis scenario. J Physiol Biochem 76: 1-12, 2020.

18. Li J, Li K and Chen X: Inflammation-regulatory microRNAs: Valuable targets for intracranial atherosclerosis. J Neurosci Res 97: 1242-1252, 2019.

19. Tao L, Xu X, Fang Y, Wang A, Zhou F, Shen Y and Li J: miR-21 targets jnk and ccr7 to modulate the inflammatory response of grass carp following bacterial infection. Fish Shellfish Immunol 94: 258-263, 2019.

20. Shoeibi S: Diagnostic and theranostic microRNAs in the pathogenesis of atherosclerosis. Acta Physiol (Oxf) 228: e13353, 2020.

21. Sessa R, Seano G, di Blasio L,Gagliardi PA, Isella C, Medico E, Cotelli F, Bussolino F and Primo L: The miR-126 regulates angiopoietin-1 signaling and vessel maturation by targeting p85 3 . Biochim Biophys Acta 1823: 1925-1935, 2012.

22. Muramatsu F, Kidoya H, Naito H, Sakimoto S and Takakura N: MicroRNA-125b inhibits tube formation of blood vessels through translational suppression of VE-cadherin. Oncogene 32: 414-421, 2013.

23. Zhang Y, Liu D, Chen X, Li J, Li L, Bian Z, Sun F, Lu J, Yin Y, Cai X, et al: Secreted monocytic miR-150 enhances targeted endothelial cell migration. Mol Cell 39: 133-144, 2010.

24. Pordzik J, Pisarz K, De Rosa S, Jones AD, Eyileten C, Indolfi C, Malek L and Postula M: The potential role of platelet-related microRNAs in the development of cardiovascular events in high-risk populations, including diabetic patients: A review. Front Endocrinol (Lausanne) 9: 74, 2018.

25. Canfran-Duque A, Rotllan N, Zhang X, Fernandez-Fuertes M, Ramirez-Hidalgo C, Araldi E, Daimiel L, Busto R, Fernandez-Hernando C and Suárez Y: Macrophage deficiency of miR-21 promotes apoptosis, plaque necrosis, and vascular inflammation during atherogenesis. EMBO Mol Med 9: 1244-1262, 2017. 
26. Chipont A, Esposito B, Challier I, Montabord M, Tedgui A, Mallat Z, Loyer X and Potteaux S: MicroRNA-21 deficiency alters the survival of Ly- $6 \mathrm{C}^{\mathrm{lo}}$ monocytes in $\mathrm{ApoE}^{-/-}$mice and reduces early-stage atherosclerosis-brief report. Arterioscler Thromb Vasc Biol 39: 170-177, 2019.

27. Huang X, Yue Z, Wu J, Chen J, Wwang S, Wu J, Ren L, Zhang A, Deng P, Wang K, et al: MicroRNA-21 knockout exacerbates angiotensin II-induced thoracic aortic aneurysm and dissection in mice with abnormal transforming growth factor- $\beta$-SMAD3 signaling. Arterioscler Thromb Vasc Biol 38: 1086-1101, 2018.

28. Li K, Cui MZ, Zhang KW, Wang GQ and Zhai ST: Effect of miR-21 on rat thoracic aortic aneurysm model by regulating the expressions of MMP-2 and MMP-9. Eur Rev Med Pharmacol Sci 24: 878-884, 2020.

29. Cong L, Yang S, Zhang Y, Cao J and Fu X: DFMG attenuates the activation of macrophages induced by coculture with LPC-injured HUVE12 cells via the TLR4/MyD88/NFKB signaling pathway. Int J Mol Med 41: 2619-2628, 2018.

30. Cong L, Zhang Y, Huang H, Cao J and Fu X: DFMG reverses proliferation and migration of vascular smooth muscle cells induced by co-culture with injured vascular endothelial cells via suppression of the TLR4-mediated signaling pathway. Mol Med Rep 17: 5692-5699, 2018.

31. Xiang X, Li L, Bo P, Kuang T, Liu S, Xie X, Guo S, Fu X and Zhang Y: 7-Difluoromethyl-5,4'dimethoxygenistein exerts antiangiogenic effects on acute promyelocytic leukemia HL-60 cells by inhibiting the TLR4/NF- $\kappa \mathrm{B}$ signaling pathway. Mol Med Rep 21: 2251-2259, 2020.

32. Lee WR, Kim KH, An HJ, Park YY, Kim KS, Lee CK, Min BK and Park KK: Effects of chimeric decoy oligodeoxynucleotide in the regulation of transcription factors $\mathrm{NF}-\kappa \mathrm{B}$ and $\mathrm{Sp} 1$ in an animal model of atherosclerosis. Basic Clin Pharmacol Toxicol 112: 236-243, 2013

33. Kim SJ, Park JH, Kim KH, Lee WR, Kim KS and Park KK Melittin inhibits atherosclerosis in LPS/high-fat treated mice through atheroprotective actions. J Atheroscler Thromb 18: 1117-1126, 2011.

34. Kim SJ, Park JH, Kim KH, Lee WR, Lee S, Kwon OC, Kim KS and Park KK: Effect of NF- $\mathrm{KB}$ decoy oligodeoxynucleotide on LPS/high-fat diet-induced atherosclerosis in an animal model. Basic Clin Pharmacol Toxicol 107: 925-930, 2010.

35. Livak KJ and Schmittgen TD: Analysis of relative gene expression data using real-time quantitative PCR and the 2(-Delta Delta C(T)) method. Methods 25: 402-408, 2001

36. Liu J, Wang X, Zheng M and Luan Q: Lipopolysaccharide from Porphyromonas gingivalis promotes autophagy of human gingival fibroblasts through the PI3K/Akt/mTOR signaling pathway. Life Sci 211: 133-139, 2018.

37. Khedoe PPSJ, de Kleijn S, van Oeveren-Rietdijk AM, Plomp JJ, de Boer HC, van Pel M, Rensen PCN, Berbee JFP and Hiemstra PS: Acute and chronic effects of treatment with mesenchymal stromal cells on LPS-induced pulmonary inflammation, emphysema and atherosclerosis development. PLoS One 12: e0183741, 2017.

38. Sheane BJ, Smyth P, Scott K, Aziz R, Buckley M, Lodge E, Kiely N, Kingston M, McGovern E, Healy M, et al: An association between microRNA-21 expression and vitamin D deficiency in coronary artery disease. Microrna 4: 57-63, 2015.

39. Nejad C, Pepin G, Behlke MA and Gantier MP: Modified polyadenylation-based RT-qPCR increases selectivity of amplification of 3'-MicroRNA isoforms. Front Genet 9: 11, 2018

40. Krützfeldt J, Rajewsky N, Braich R, Rajeev KG, Tuschl T, Manoharan M and Stoffel M: Silencing of microRNAs in vivo with 'antagomirs'. Nature 438: 685-689, 2005.

41. Hermkens DMA, Stam OCG, de Wit NM,Fontijn RD, Jongejan A, Moerland PD, Mackaaij C, Waas ISE, Daemen MJAP and de Vries HE: Profiling the unique protective properties of intracranial arterial endothelial cells. Acta Neuropathol Commun 7 : $151,2019$.

42. Zeng Y, Xu J, Hua YQ, Peng Y and Xu XL: MDM2 contributes to oxidized low-density lipoprotein-induced inflammation through modulation of mitochondrial damage in endothelial cells. Atherosclerosis 305: 1-9, 2020

43. Virani SS, Alonso A, Benjamin EJ, Bittencourt MS, Callaway CW Carson AP, Chamberlain AM, Chang AR, Cheng S, Delling FN, et al: Heart disease and stroke statistics-2020 update: A report from the American heart association. Circulation 141: e139-e596, 2020

44. Varela ML, Mogildea M, Moreno I and Lopes A: Acute inflammation and metabolism. Inflammation 41: 1115-1127, 2018.
45. Aghasafari P, George U and Pidaparti R: A review of inflammatory mechanism in airway diseases. Inflamm Res 68: 59-74, 2019.

46. Skaper SD, Facci L, Zusso M and Giusti P: An inflammation-centric view of neurological disease: Beyond the neuron. Front Cell Neurosci 12: 72, 2018

47. Tan H, Zhao J, Zhang H, Zhai Q and Chen W: Novel strains of Bacteroides fragilis and Bacteroides ovatus alleviate the LPS-induced inflammation in mice. Appl Microbiol Biotechnol 103: 2353-2365, 2019.

48. Wu X, Zhang LL, Yin LB, Fu YJ, Jiang YJ, Ding HB, Chu ZX, Shang $\mathrm{H}$ and Zhang ZN: Deregulated microRNA-21 expression in monocytes from HIV-infected patients contributes to elevated IP-10 secretion in HIV infection. Front Immunol 8: 1122,2017

49. Lu Y, An Y, Lv C, Ma W, Xi Y and Xiao R: Dietary soybean isoflavones in Alzheimer's disease prevention. Asia Pac J Clin Nutr 27: 946-954, 2018

50. Gholampour F, Mohammadi Z, Karimi Z and Owji SM: Protective effect of genistein in a rat model of ischemic acute kidney injury. Gene 753: 144789, 2020.

51. Das G, Paramithiotis S, Sundaram Sivamaruthi B, Wijaya $\mathrm{CH}$, Suharta S, Sanlier N, Shin HS and Patra JK: Traditional fermented foods with anti-aging effect: A concentric review. Food Res Int 134: 109269, 2020.

52. Petry FDS, Coelho BP, Gaelzer MM, Kreutz F, Guma FTCR, Salbego CG and Trindade VMT: Genistein protects against amyloid-beta-induced toxicity in SH-SY5Y cells by regulation of Akt and Tau phosphorylation. Phytother Res 34: 796-807, 2020.

53. Ahmad Z, Ng CT, Fong LY, Bakar NA, Hussain NH, Ang KP, Ee GC and Hakim MN: Cryptotanshinone inhibits $\mathrm{TNF}-\alpha$-induced early atherogenic events in vitro. J Physiol Sci 66: 213-220, 2016

54. Unver N and McAllister F: IL-6 family cytokines: Key inflammatory mediators as biomarkers and potential therapeutic targets. Cytokine Growth Factor Rev 41: 10-17, 2018.

55. Richards J, El-Hamamsy I, Chen S, Sarang Z, Sarathchandra P, Yacoub MH, Chester AH and Butcher JT: Side-specific endothelial-dependent regulation of aortic valve calcification: Interplay of hemodynamics and nitric oxide signaling. Am J Pathol 182: 1922-1931, 2013

56. Cassini-Vieira P, Araujo FA, da Costa Dias FL, Russo RC, Andrade SP, Teixeira MM and Barcelos LS: iNOS activity modulates inflammation, angiogenesis, and tissue fibrosis in polyether-polyurethane synthetic implants. Mediators Inflamm 2015: 138461, 2015 .

57. Bellucci A, Bubacco L, Longhena F, Parrella E, Faustini G, Porrini V, Bono F, Missale C and Pizzi M: Nuclear Factor $-\kappa B$ Dysregulation and $\alpha$-synuclein pathology: Critical interplay in the pathogenesis of Parkinson's disease. Front Aging Neurosci 12: $68,2020$.

58. Zhang Q, Lenardo MJ and Baltimore D: 30 Years of NF-кB: A blossoming of relevance to human pathobiology. Cell 168: 37-57, 2017.

59. Skvortsova K, Iovino $\mathrm{N}$ and Bogdanovic O: Functions and mechanisms of epigenetic inheritance in animals. Nat Rev Mol Cell Biol 19: 774-790, 2018.

60. Hulshoff MS, Del Monte-Nieto G, Kovacic J and Krenning G: Non-coding RNA in endothelial-to-mesenchymal transition. Cardiovasc Res 115: 1716-1731, 2019.

61. Singh RP, Massachi I, Manickavel S, Singh S, Rao NP, Hasan S, Mc Curdy DK, Sharma S, Wong D, Hahn BH and Rehimi H: The role of miRNA in inflammation and autoimmunity. Autoimmun Rev 12: 1160-1165, 2013.

62. Das A, Ganesh K, Khanna S, Sen CK and Roy S: Engulfment of apoptotic cells by macrophages: A role of microRNA-21 in the resolution of wound inflammation. J Immunol 192: 1120-1129, 2014.

63. Xue Z, Xi Q, Liu H, Guo X, Zhang J, Zhang Z, Li Y, Yang G, Zhou D, Yang H, et al: miR-21 promotes NLRP3 inflammasome activation to mediate pyroptosis and endotoxic shock. Cell Death Dis 10: 461, 2019.

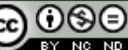

This work is licensed under a Creative Commons Attribution-NonCommercial-NoDerivatives 4.0 International (CC BY-NC-ND 4.0) License. 